UDC 159.953 (477): 94 (100) «1914/1918»

DOI: $10.24919 / 2519-058 x .11 .170708$

\title{
Borys SAVCHUK
}

PhD hab. (History), Professor, Professor of the Department of Pedagogy named after Bogdan Stuparik of Vasyl Stefanyk Precarpathian University, 57 Shevchenko Street, Ivano-Frankivsk, Ukraine,postal code 76000 (boris_savchuk@ukr.net)

ORCID: org/0000-0003-2256-0845

ResearcherID:https://publons.com/researcher/2903385/boris-savchuk/

\section{Halyna BILAVYCH}

Ph D hab. (Education), Professor, Professor of the Department of Pedagogy of Primary Education of Vasyl Stefanyk Precarpathian University, 57 Shevchenko Street, IvanoFrankivsk, Ukraine, postal code 76000 (ifosuhcvas@gmail.com)

ORCID: org/0000-0002-1555-0932

ResearcherID: https://publons.com/researcher/2151427/galyna-v-bilavych/

\section{Борис САВЧУК}

доктор історичних наук, професор кафедри педагогіки імені Богдана Ступарика Прикарпатського національного університету імені Василя Стефаника, вул. Шевченка, 57,.м. Івано-Франківськ, Україна, індекс 76000 (boris_savchuk@ukr.net)

\section{Галина БІЛАВИЧ}

доктор педагогічних наук, професор, професор кафедри педагогіки початкової освіти Прикарпатського національного університету імені Василя Стефаника, вул. Шевченка, 57,.м. Івано-Франківськ, Україна, індекс76000 (ifosuhcvas@gmail.com)

Бібліографічний опис статті: Savchuk, B. \& Bilavych, H. (2019). Necropolises of the Austrro-Hungarian Army in Precarpathian during World War I. Skhidnoievropeiskyi istorychnyi visnyk [East European Historical Bulletin], 11, 133-141. doi: 10.24919/2519-058x.11.170708

\section{NECROPOLISES OF THE AUSTRRO-HUNGARIAN ARMY IN PRECARPATHIAN DURING WORLD WAR I}

Summary. The purpose of the research is to find out the location, the place and the state of conservation of the burials of the soldiers of the Austro-Hungarian army on the territory of Precarpathian (Ivano-Frankivsk Region) during the period of World War I. The methodology of the research is based on the principles of historicism, systematic and scientific approaches, objectivity, the use of general scientific (analysis, synthesis, generalization) and special-historical (historical-genetic, historical-typological, historical-systematic) methods. The novelty is the classification and the substantive analysis of the military necropolises of the Austro-Hungarian army according to certain groups have been carried out; the changes in their architectonics (quantity, character of the location, etc.) that have taken place over the centuries have been determined; the process of the natural burial of the fallen soldiers of the Austro-Hungarian and other armies in the individual and group burials and in the separate sections of 
urban, rural, parish cemeteries at the initial stage of the war has been reconstructed; etc. Conclusions. Thus, according to the developed model of the study, the graves at the military cemeteries in the above mentioned territory in 1914 - 1918 and the civilian cemeteries on the grounds of the belonging of the soldiers to the rival armies and the nationality of the soldiers are classified into two main groups: 1) common to the servicemen of the Austro-Hungarian and Russian armies; 2) separate, where the Austro-Hungarian Army soldiers are buried. Among them there were predominant the individual and group burials, scattered on the fields, the private farmsteads, along the roads, and also the separate sections in the urban and rural cemeteries. As a result of the changes (transferring, reburial, a natural and conscious destruction, etc.) that took place over the next decades, at the beginning of the twenty-first century there were almost no graves outside the cemetery, but in different conditions the separate military necropolises were preserved in the urban and rural cemeteries, many of them in a miserable condition. These necropolises require a special protection from the state. Up to date is the preparation of the generalized fundamental works on the military necropolises of Ukraine on the basis of the results integration of the relevant regional studies.

Key words: World War I, Precarpathian, Austro-Hungarian army, military burial, military cemetery, military necropolis, military graves.

\section{НЕКРОПОЛІ АВСТРО-УГОРСЬКОЇ АРМІї ДОБИ ПЕРШОЇ СВІТОВОЇ ВІЙНИ НА ПРИКАРПАТТІ}

Анотація. Мета дослідження полягає у з'ясуванні локалізації, розташування та стану збереження поховань воїнів австро-угорської армії періоду Периої світової війни на території Прикарпаття (Івано-Франківщчни). Методологія дослідження грунтується на принципах історизму, системності, науковості, об 'єктивності, використання загальнонаукових (аналіз, синтез, узагальнення) та спечіально-історичних (історико-генетичний, історико-типологічний, історико-системний) методів. Новизна дослідження полягає в тому, ш⿻ здійснено класифікацію і предметний аналіз військових некрополів австро-угорської армії за визначеними групами; з 'ясовано зміни в їхній архітектонічі (кількість, характер розташування тощо), шео відбулися епродовж століття; реконструйовано процес стихійного поховання загиблих воӥнів австро-угорської та інших армій в індивідуальних і групових захороненнях та окремих ділянках міських, сільських, парафіяльних ивинтарів на початковій стадї війни; тошчо. Висновки. Отже, згідно з розробленою моделлю дослідження, поховання на військових иявнтарях краю 1914 - 1918 рр. і ичивільних кладовищах за ознаками приналежності вояків до ворогуючих армій та за начіональністю войнів класифіковано на дві основні групи: 1) спільні для військовослужбовців австро-угорської і російської армій; 2) окремі, де поховані загиблі австроугорської армії. Серед них переважали індивідуальні і групові поховання, розкидані на полях, приватних садибах, уздовж доріг тошо, а також у вигляді окремих ділянок на міських і сільських ивинтарях. Унаслідок змін (перенесення, перепоховання, природне $і$ свідоме руйнування тошь), шчо відбулися впродовж наступних десятиліть, на початку XXI cm. поховань за межами иявинтарів майже не залишилося, натомість у різному стані збереглися окремі військові некрополі на міських і сільських извинтарях, багато з них у жалюгідному стані. Ці некрополі потребують особливої охорони з боку держави. На часі також підготовка узагальнювальних фундаментальних праць про військові некрополі України на основі інтеграції результатів відповідних регіональних студій.

Ключові слова: Перша світова війна, Прикарпаття, австро-угорська армія, військове поховання, військове кладовище, військовий некрополь, військові могили.

Problem statement. World War I (the Great War) drastically changed the history of the XXth century, it became a tragedy for millions of families. Its study is conducted on the continental, national, regional and interdisciplinary levels and covers the socio-political, 
military, socio-economic, cultural and everyday spheres. These and other aspects accumulate the problem of the military burials, on which there is a long-term social and scientific discourse. The current situation in Ukraine regarding the preservation of the military graves is characteristic of other European countries and has its own peculiarities.

The topicality of the study of the military cemeteries of 1914-1918 in Precarpathian (we outline the territorial and administrative boundaries of Stanislav voyevodstvo in the 20-ies and 30-ies of the 20 th century, which generally coincide with the borders of modern Ivano-Frankivsk Region) is due to a number of factors: a) there is a general shifting of the emphasis on studying of the identified issues at the regional level; b) the registration of graves and graveyards is mainly carried out within the limits of the separate administrative units; c) the military burials of Ivano-Frankivsk region have been investigated worse than in many other regions of Ukraine, although their size is not less significant; d) their study at the «micro level» allows to show more deeply the general and special features, the tendencies of the formation of the military necropolises of Ukraine.

The analysis of sources and recent researches. The problem stated above was not the subject of a special scientific research, but only a fragmentary analysis done by the ethnologists (Y. Balitska (Balitska, 2011), P. Vorobets (Vorobets, 2010), O. Kozak (Kozak, 2016), L. Orel, R. Chornenkyi, P. avrylyshyn (Orel, Chornenkyi, \& Havrylyshyn, 2012)). The analysis of their work shows that a comprehensive study of the history of the formation and a modern state of the military memorials should be launched at the regional level, as this creates the basis for the preparation of the generalized fundamental works.

The publication's purpose is to find out the location, the place and the state of conservation of the burials of the soldiers of the Austro-Hungarian army on the territory of Precarpathian (Ivano-Frankivsk Region) during the period of World War I. To achieve the goal of the research certain problematic issues must be solved: to define the main terms and the sources of the research; to elaborate the classification of the military burials of the Austro-Hungarian army and to carry out their substantive analysis; to find out the changes in the architectonics of the military burials that have taken place over the centuries.

Statement of the basic material. We use the terms «necropolis», «cemetery» as synonyms without going deep into the discourse on the interpretation of the above mentioned concepts. We use the term «military necropolis» in a broad sense to refer to the burial places of soldiers of various armies and nationalities that participated in the Great War of 1914 1918; the term «military cemetery» (in German - Kriegerfriedhof, in Polish - Cmentarz wojskowy) is understood as a place of burial of different armies servicemen; the term «war cemetery (German - Kriegsfriedhof, Polish - Cmentarz wojenny) - as a place where all the victims of the war, the civilians and the oldiers were buried.

38 states with 1.5 billion people were involved into the Great War. Carpathian region was in the epicenter of the East European «theater» of military activities between the AustroHungarian and German armies - on the one hand, and the Russian army - on the other hand. The general tendency has been revealed, according to which, the character and the dynamics of the deployment and localization of the military actions in Precarpathian region as the «puzzlesmatrix» coincide with the appearance and geography of the military burials location. 
The number of the dead soldiers of the warring armies during World War I and the number of the military cemeteries that appeared in Stanislavivshchyna after its end, can be spoken about only conventionally. A clear insight is given by the data of 1920 on the territory of the Lviv Austro-Hungarian military command (KuK Militärkommando Lemberg), which included the territories of the region. According to the data, there were 610 military cemeteries in the area from 1914 to 1919, of which 467 were individual. Among the 227130 people buried, there were 108220 warriors of the Austro-Hungarian army. Their remains rested in tens of thousands of the individual and group burials (Kozak, 2016). Taking into consideration the fact that Stanislavivshchyna was almost the third of the territory of the Lviv Austro-Hungarian military command, we can assert that in the post-war years there were about two hundred military cemeteries with several thousand individual and group burials.

At the initial stage of the Great War, the Austro-Hungarian army did not have a clear doctrine regarding the burial of the dead soldiers, and when their numbers began to grow rapidly, it became spontaneous. In the times of calm periods between the battles, therefore, with the stabilization of the front line, comrades of arms and the rear services, on the one hand, and the local people voluntarily or coercion, on the other hand, buried the soldiers in their place of death or pulled the bodies to the funnels and covered them with the ground. On the site of such sanitary graves the embankments were left, which in size corresponded to the individual and group (brotherly) graves. The crosses were erected. Otherwise, the peasants brought the bodies of the victims to the parish cemeteries and buried them «where the free space was». Later on, this process became organized, and some sections of the military burial grounds were established. Simultaniously, the military cemeteries were created.

The systematic ordering of the military burials in the Austro-Hungarian army began with the creation of the Ninth Division of Military burials (the 9th Kriegsgräberabteilung) on December 3, 1915, in the structure of the Ministry of War. The Ninth Division of Military burials functioned until November 1, 1918. Its tasks consisted in realizing the records of the dead, carrying out the exhumation and the reburial of the remains and designing, erecting and equipping the military cemeteries, etc. The inspections of the military burials (Kriegsgräberinspektion) were created in the districts under conditions of the war. In particular, Stanislavivshchyna belonged to the Military District «Lviv» (K. und k. Kriegsgräberinspektion des Militärkommandos Lemberg). The Inspections, the special labor brigades (Arbeiterabteilung) were subordinated to, had the separate districts fixed. Their competence included the issue of legal, organizational, logistical support for the process of the creation and operation of the military cemeteries and the recording and burial memorialization (Kozak, 2016).

In Halician governorate general, formed on the territory of the region during its transition to the power of Russia, the functions of accounting and ordering burials of dead soldiers were carried out by the police.

The documents from the funds of the Ivano-Frankivsk Regional State Archive give important insights on the nature and peculiarities of the formation of the military cemeteries of Carpathian region during the Great Battle of the architectonics. We focus on the individual areas for the typology of this phenomenon. 
In the list made by the organs of the Russian police in June 1916 - July 1917, «The List of graves of soldiers of the hostile army in Kosiv district», 65 burial facts (about one hundred individual and 3 group graves) are described according to the following features: a) the location (the village, the road, the other object); b) the presence of crosses, the material the crosses are made of, the inscriptions on them; c) the kind the fences are; d) the general condition, the special features. The analysis showed that about a quarter of the burials were located in the rural cemeteries; about 11 - along the roads, the bog lands and pastures, the rest - in private farmsteads and fields. On most graves there were hewn or non-cultured crosses made of oak, beech, birch, fir, and some had stone pedestals and fences made of wire. Only fifteen dozen crosses had the inscriptions with the names of the soldiers (SAIFR, f. 12, d. 1, c. 167 , pp. 29-34).

According to our calculatins, 102 graves of the soldiers of Russian and Austro-Hungarian armies were registered in 23 settlements, which belonged to the 1st Police Department of Kolomyia District. 50 and 20 of these are in the cemeteries of the villages of Malyi Hvizdets and Hvizdets (SAIFR, f. 605, d. 1, c. 20, p. 11).

The list of the graves of the warring army soldiers on the Usteritska territory Kosiv district illustrates the national composition of the dead. In particular, as a result of the battles in August - September 1916 in the village Yablonytsya there appeared the burial of the officer of the 23rd reserve corps (in the document «regiment») of the German army, Viliano Corde, and the burials of several dozen soldiers of various units of the German, Austro-Hungarian, and Russian armies (SAIFR, f. 12, d. 1, c. 168 , pp. 40-43).

Such a fragmentary review allows us to make an interim conclusion. Most of the burials of the soldiers of the Austro-Hungarian army, which arose during the period of the Great War, were not preserved under current conditions, and therefore the architectonics of the military necropolis of Precarpathians at the beginning of the XXIst century is fundamentally different. It is based on the military cemeteries and war graves sites laid in $1914-1918$ on the civilian and military cemeteries, which have also undergone the significant changes over the next decades. We can speak quite arbitrarily about their number and more over about the number of soldiers buried there. The generalization of the accumulated sources allows to record about 140 burials of soldiers of the Austro-Hungarian, German and Russian armies and the national military formations on the territory of Precarpathian during World War I in the form of the military cemeteries, the sections of the military burials in urban, rural, church cemeteries and mass graves. This number does not take into account individual graves on the territory of the cemeteries and the graves, scattered in forests, fields, roads, etc.

The burials on the military cemeteries of $1914-1918$ and on the civilian cemeteries are divided into two main groups in accordance with the belonging of the soldiers to the warring armies: 1) common for the servicemen of the Austro-Hungarian and Russian armies; 2) separate, where the soldiers of the Austro-Hungarian army were buried. These groups of necropolises are structured and characterized by the number of burials, the localization and the features of the location, the state of preservation of tombstones, the memorial immortality, and other features. 
To the first of the identified groups belongs is about $20 \%$ of the designated number of burials. They are the largest in the number of the buried and are represented by the separate military cemeteries and sections on the civilian cemeteries. One of the largest in Carpathian region is the military necropolis in the tract of Rivnya near the village of Tyshkivtsi in Horodenka district, where about three thousand soldiers of the Austro-Hungarian and Russian armies were buried in three brotherly graves, who perished during June battles of 1916 (Nekropoli, 2000, p. 102). Not far away, in Korniv, another large burial place was preserved as the part of the graves with several hundred soldiers of these armies (Nekropoli, 2000, p. 99).

The necropolises of World War I in Ivano-Frankivsk have a difficult and tragic history. The fate of one of the oldest central city cemetery in Ukraine (founded in 1782) is indicative, now called «Memorial Square». From the beginning of World War I in its southern part - on a «new field», which belonged to the Greek-Catholic capitol, a military cemetery was founded. At first, the Russian soldiers were buried here (about 800 people in 317 graves); later - the soldiers of the Austro-Hungarian army, who died at the front or died in hospitals (one of the oldest military hospital in Eastern Europe functioned in the city). After ordering from 1924 to 1927, it became the main military cemetery of Stanislav, where 665 graves of soldiers, who died in the Great War, (Orel, Chornenkyi, \& Havrylyshyn, 2012) were located.

At the other «new» cemetery of Stanislav (founded in 1912) since the beginning of World War I, the soldiers of various armies were buried, but their burials were not preserved. In their place in the 1950-ies the graves of servicemen of the Soviet secret services units appeared (Nekropoli, 2000, pp. 26-27).

Large military cemeteries of the soldiers of the Austro-Hungarian and Russian armies are also located in the town of Dolyna (more than 300 small concrete crosses have been preserved) and in the village Vyshkiv, Dolinskyi district.

The best preserved are the military burials, in particular, the tombstones that make up the separate sections of village and church cemeteries. Among the dozens of such facts we will single out the cemetery in the village of Bliudnyky, Halytskyi district, where about one hundred soldiers of the Austro-Hungarian and Russian armies, who were killed in the battle on June 4,1916 , were buried. They are marked with 25 low earthen embankments with Latin crosses (Mista i sela, 2012, p. 85; Nekropoli, 2000, p. 84). In the 1920-ies, the remains of one and a half hundred soldiers of these armies, settled in separate graves in the tract of Zahostynets of the village of Bryn of the same district, were reburied in the village cemetery in a fraternal grave, which was made in the form of a high cone-shaped embankment with a tomb (Mista $i$ sela, 2012, p. 88). By the efforts of the local communities and the church fraternities, several tens of graves of the soldiers of the Austro-Hungarian and Russian armies (1914 - 1916) are kept in a good condition in the old village cemeteries in Nyzhniy Bereziv, Kosiv district, in Korniv, Horodenkiv district (Nekropoli, 2000, pp. 99, 125) and others. Of the 25 burials of the soldiers of the Austro-Hungarian Army belonging to the second group, we mention one of the largest military cemeteries of Precarpathian town of Rohatyn. It has a complex structure and history, which in typical and unique dimensions is characteristic for the formation of many other military necropolises. In its structure, it is a single complex of three separate parts. The 
largest are the burials on the left bank of the river Hnyla Lypa, where numbering on the crosses of the individual graves is indicated by figures from 407 to 572 . In addition to them, there are three fraternal graves on which there are eight crosses and a two-meter monument with the inscription in German «Zu unseren Helden 1916». («To Our Heroes / 1916»). The second part is the burial ground at the cemetery near the church of the Holy Spirit (20 graves with crosses marked with numbers from 573 to 595); the third - 36 graves (from 599 to 652) in the town cemetery. The numbering indicates the integrity of the necropolis and means that the rest of the graves were not preserved (Vorobets, 2010). In these locally separated parts of the dead soldiers were buried in individual, group and fraternal graves. They were taken from the front, the town hospital, as well as from the Church of the Nativity of the Blessed Virgin Mary, the cathedral of St. Nicholas, the secular buildings, where the Russian prisoners of the war were mostly held, and the others like that. The funeral service teams marked each grave with the concrete crosses made by the local craftsmen, and fixed on them the numbers made of the galvanized plaques. Due to this, under present conditions the buried soldiers are identified on the basis of the registration lists stored in Vienna military archives. With the assistance of the Austrian Consulate and the international organization «Black Cross», the memorial is constantly kept in order, in particular, 80 tomb crosses and a memorial sign were established (Vorobets, 2010).

The memorial complex was preserved on the old cemetery of Kalush in a more integral form, where about 300 soldiers (1916 - 1917) of the Austro-Hungarian army were buried. It occupies the territory in the southern part (the area of $50 \mathrm{~m} \times 50 \mathrm{~m}$ ), where there are $30-35$ graves in seven rows from the north to the south and 10-15 graves in eight rows from the west to the east. In 1930 the half-meter Latin crosses with inscriptions of the personal data of the buried were installed on each tombstone. The inscriptions were written in Latin (Nekropoli, 2000, p. 47).

The architectonics of the tombs of the Austro-Hungarian army soldiers is quite mosaic. We will note the military cemetery in the village of Maidan in Tysmenytsia district as the example, reflecting the typical and specific features of the cemetery formation and the present state. At the cemetery where in more than 200 individual graves the soldiers of the Austro-Hungarian Army are buried, who died in hospitals in 1916 - 1917 (crowned with the monorange crosses and the main cross) (Nekropoli, 2000, p. 168); the great fraternal grave of the German and Austrian soldiers, killed in 1915, at the town cemetery in Horodenka (Nekropoli, 2000, p. 96); the village military cemetery in Kulachkivtsi in Snyatynskyi district, where the Austrian soldiers and villagers were buried, who died in 1914 - 1919, and the others. (Nekropoli, 2000, p. 159). The column with a marble board, which was destroyed during the Soviet period, distinguished the site with 9 graves of the Austrian soldiers at the village cemetery of the village Borschov in the same district, where the remains were brought from the tract Hora in 1929. A large burial was preserved of 10 group and individual graves of the soldiers of the Austro-Hungarian army, who died in 1917 in one of the last major battles in Precarpathian region. This large burial was preserved in a separate section at the church yard in the village of Mizhhirya in Bohorodchanskyi district (Zvid pamiatok, p. 202).

The traces of the Croatian military graves did not fade either (Ustya village of Snyatyn district, Fytkiv village of Nadvirna district (Nekropoli, 2000, p. 165)). The most famous 
became the Croatian military necropolis in the village of Hlybivka in Bohorodchany district, where 51 soldiers, who died in 1916, were buried in the churchyard. The gate was preserved and brought from Vienna in 1917 by a monument with a carved inscription, which testifies the burials of the Croatian soldiers of the 25th Zagreb and the 26th Karlovac Regiments of the Austro-Hungarian Army, who "gave their lives for their homeland and for the king» (Zvid pamiatok, p.78). In November 2016, on the initiative of the Republic of Croatia, the memorial complex was opened here.

The so-called plague cemeteries, singled out into a separate group, are divided into two subgroups in the context of the problem under study. To the first group we refer the civilian cemeteries, where the soldiers were buried, who died of various infectious diseases; to the second - actually the military burials. The remnants of such a large cemetery have been preserved in the suburbs of Rohatyn, where there are about 250 graves in the section of 40 $\mathrm{m} \times 60 \mathrm{~m}$ sq., located in 8 rows, 26 graves in each, and the single graves. Judging by the personal numbers, engraved on the half-meter concrete crosses, the remains of the soldiers of the Austro-Hungarian army, who died in 1915 - 1916, were buried there. After the war, the monument was erected at the cemetery with the inscription in Polish «Do naszych bohaterów» («To Our Heroes») (CHCMIFR - Zvit, p. 4). At the cemetery of the buried soldiers of World War I in Kalush in 2011, besides 358 burials of the soldiers of various armies, a separate area was found where the buried soldiers of various armies, who died in 1917 - 1918 in the town infectious barracks (Balitska, 2011).

Conclusions. The Necropolis of the Austro-Hungarian Army of Precarpathian during World War I has a large number of varieties of burials. It began to be formed in 1914 1920 and during the following century it underwent the qualitative changes: the majority of the grouped and individual burials outside the cemeteries, except those reburied at the cemeteries in the 1920-ies - 1930-ies, was not preserved. Most of the burials in the urban and rural cemeteries, formed in 1914 - 1918, are no longer fixed in the contemporary necropolis studies, and many detached graves sites that survived at the military cemeteries are now in a miserable condition.

The further research of this problem should be developed in the direction of preparing the generalized fundamental works on the military necropolis of Ukraine on the basis of the integration of the results of the relevant regional studies. Perspective is the study of the burials of the soldiers of the Russian army and various national military formations in separate regions of the country.

Acknowledgments. The authors express their gratitude to the employees of the State Archive of Ivano-Frankivsk region for the help in finding the historical documents.

Funding. The authors received no financial support for the research, authorship, and/or publication of this article.

\section{BIBLIOGRAPHY}

Balitska, Yu. (2011). Na staromu tsvyntari narakhuvaly bilshe 300 mohyl voiakiv avstriiskoi armii [More than 300 Graves of Austrian Army Soldiers were Reckoned on the Territory of Old Cemetery]. Vikna. 4 - 10 lystopada. [in Ukrainian].

Derzhavnyi arkhiv Ivano-Frankivskoi oblasti [SAIFR - State Archive of Ivano-Frankivsk Region]. 
Kozak, O. (2016). Orhanizatsiia memorialnoi spravy na terytorii Skhidnoi Halychyny ta Lvivskoho voievodstva iz 1914 do 1939 roku [Organization of Memorial Deed on the Territory of Eastern Halychyna and Lviv Voyevodstvo from 1914 to 1939]. URL: http://geroika.org.ua/ [in Ukrainian].

Mista i sela Halytskoho raionu: istoriia, pamiatky, osobystosti.(2012). [Towns and Villages of Halytskyi District: History, Monuments, Personalities]. Ivano-Frankivsk: Nova Zoria, 784 p. [in Ukrainian].

Nekropoli Prykarpattia. [Necropolises of Precarpathian]. Ivano-Frankivsk, 2000. 178 p. [in Ukrainian].

Orel, L., Chornenkyi, R., \& Havrylyshyn, P. (2016). Mify staroho nekropolia [Myths of Old Necropolis]. Halytskyi korespondent. 5 kvitnia. [in Ukrainian].

Vidomchyi arkhiv Naukovo-redaktsiinoho viddilu «Zvid pamiatok istorii ta kultury. IvanoFrankivska oblast» [CHCMIFR - Collection of History and Culture Monuments. Ivano-Frankivsk Region]. Zvit pro vykonanu robotu v Kolomyia iza 4 kvitnia 2007 r. Oliinyk Myroslavy Vasylivny. [Report on Accomplished Work in Kolomyia from April, 4 2007].[in Ukrainian].

Vorobets, P. (2010). Nezitretsia z pamiati pokolin [Will not Be Erased from the Memory of Generations]. Holos Opillia. 23 zhovtnia. [in Ukrainian].

Zvid pamiatok Ivano-Frankivskoi oblasti: Bohorodchanskyi raion [Collection of Monuments of Ivano-Frankivsk Region: Bohorodchanskyi District] (2008). Ivano-Frankivsk: Lileia-NV, 331 p.[in Ukrainian].

The article was received on February 19, 2019. Article recommended for publishing 10/06/2019. 